This item is the archived peer-reviewed author-version of:

Resurrection in slow motion : the delayed restoration of the cinema exhibition industry in post-war Rotterdam (1940-65)

\title{
Reference:
}

Van Oort Thunnis.- Resurrection in slow motion : the delayed restoration of the cinema exhibition industry in post-w ar Rotterdam (1940-65) European review of history - ISSN 1350-7486 - 25:6(2018), p. 999-1017

Full text (Publisher's DOI): https://doi.org/10.1080/13507486.2017.1374928

To cite this reference: https://hdl.handle.net/10067/1521540151162165141 


\section{Resurrection in Slow Motion. The Delayed Restoration of the Cinema Exhibition Industry in Post-War Rotterdam (1940-1965)}

Thunnis van Oort

One of the central questions in the debates about the history of movie-going in the

Netherlands centres on why the size and amount of cinemas and cinema visits per capita has been significantly below the average in Western Europe throughout most of the $20^{\text {th }}$ century. ${ }^{1}$ Both cultural and economic explanations have been offered for this Dutch deviation, sometimes combined. A typical 'cultural' argument points to an unfavourable influence of Calvinism on visual culture and entertainment taking place outside of the home in general, and film viewing in particular. ${ }^{2}$ In response, Karel Dibbets has suggested a more complex interplay of socio-political and business-economic factors that caused the underdeveloped market for film consumption in the Netherlands. ${ }^{3}$

Cinema did not assimilate into the segmented Dutch society that was characterised by Protestant, Catholic, Socialist, and (to a lesser extent) Liberal 'pillars': networks of political parties, unions, schools, housing corporations, health care institutions, and media platforms such as radio and newspapers. But not cinema. In southern neighbour Belgium, that was 'pillarised' in a similar fashion, Catholic and Socialist cinemas did appear, whereas in the Netherlands the cinema remained to a large part excluded from the pillars. ${ }^{4}$ According to 
Dibbets, national and local governments, opposing what they viewed as an undesirable new form of leisure, weakened demand for film consumption by levying high cinema taxes, imposing strict censorship and generating a unfavourable discourse on movie going. In reaction to unsympathetic governments and cultural elites, the industry formed a strong cartel, that could counter the limited demand for film by controlling the supply-side, keeping prices high. This cartel was institutionalised in the form of the Nederlandse Bioscoopbond (Netherlands Cinema Alliance, hereafter NBB), established in 1921.

Dibbets' hypothesis was tested empirically by Sedgwick, Pafort-Overduin and Boter in their comparison of Dutch, English, and to a lesser extent, Australian, film markets in the 1930s. ${ }^{5}$ Dibbets' assumption was confirmed that, at least during the 1930s, cinema admissions were relatively highly priced in the Netherlands: even though Dutch film goers spent a similar percentage of their budget on the cinema, their British counterparts went much more often.

Both Dibbets and Sedgwick et al. recognise the crucial role of the NBB. This warrants a closer investigation of how this cartel operated than they could provide in their work, especially with focus on the period after the Second World War, when its power was at its peak. Elsewhere, I have argued that the NBB functioned as a cartel, in sharp contrast to the much more liberal market conditions in neighbouring Belgium. ${ }^{6}$ The present article further explores how the NBB functioned by looking more closely at a specific case study: the city of Rotterdam, second largest city of the country. The reconstruction of the cinema industry in Rotterdam, that was heavily damaged during the Second World War, merits a closer look because it allows us to monitor how the cinema was literally (re)positioned in the new city 
centre. The primary focus will be on the regulation of competition through the business association NBB, and the relations with outside actors such as government and (would-be) film exhibitors that were considered outsiders by the Rotterdam cinema entrepreneurs. As sources the trade press is used, and especially the extensive archives of the NBB, allowing a look behind the scenes of the industry. Investigating a cultural industry such as the cinema exhibition sector offers distinct opportunities to improve our understanding of dynamic intersections between economic, social, and cultural history.

\section{The NBB: A Cinema Cartel}

Before turning to post-war Rotterdam, I will provide a brief overview of the development of the NBB as a business network central to the Dutch cinema industry. During World War I, in which the Netherlands remained neutral, cinema exhibition was booming and also the number and scale of companies specialised in film distribution increased. In 1916 a weekly film exchange started in Amsterdam, that quickly grew into an informal platform that was later formalised into a business association. Film exhibitors formed the 'Bond van exploitanten van Nederlandsche bioscooptheaters' (association of Dutch cinema exhibitors) in 1918. A crucial change took place in 1921 when the NBB united exhibitors and distributors into a single business association, a highly uncommon alliance when seen in international perspective. ${ }^{7}$ The structuring of the Dutch industry was markedly different from the Anglo-Saxon model as it developed not only in the United States and Britain but also for example in neighbouring 
Belgium where distributors set the terms for how the industry was organised, establishing a hierarchy of 'runs' in which the first-run cinemas charged much higher admission prices than theatres in the lower regions. Independent exhibitors were free to enter an open market, in contrast to the Dutch situation, where the power division between the two branches of the industry was less clear-cut. In the end, mutual disagreements were subordinated by Dutch distributors (wholesalers) and exhibitors (retailers) to the shared advantages of 1 ) a strong and united representation towards government institutions, and international suppliers such as the American film exporters, and 2) a robust internal regulation.

Van der Velden et al. have pointed out the driving force behind the NBB as a small group of the larger entrepreneurs active in distribution and exhibition combined, operating on a supralocal scale, as opposed to the majority of smaller businesses that consisted mostly of exhibitors operating often a single venue in a local market. ${ }^{8}$ The opposing interests of those two groups caused tensions that were only barely resolved during the first half of the 1920s. The small entrepreneurs were persuaded to join the NBB because the organization demonstrated a successful, aggressive opposition against municipal governments that levied high entertainment taxes. The NBB also lobbied extensively at the national government in the process of cinema censorship legislation, that took the better part of the decade to finally go into effect in 1928. It was in 1926 that the NBB consolidated its strong power base by adopting its exclusivity decree: members agreed that in the Netherlands no films could be bought, sold or rented (out) by non-members, making NBB membership unavoidable for anyone in the business. This gave the NBB the potent instrument of the boycott, or even expulsion: members that did not comply to the regulations, could be cut off from film supply 
or customers. The fact that the NBB represented the complete industry laid the foundation for the cartel agreements that were effective for decades and covered various aspects of doing business in the Dutch cinema sector.

The NBB was an exponent of cartelisation that was far from exceptional in (Northern) European commerce. As opposed to Anglo-Saxon countries such as the United States and the United Kingdom, where cartels were being criminalised since the late nineteenth century, cartel agreements were a government-sanctioned practice in many European countries, where corporatist collaboration in networks of companies, government and other stakeholders were dominant features of the business system. ${ }^{9}$ The crisis of the 1930s instigated the heydays of the cartels in the Netherlands, amounting to an estimated $60 \%$ of Dutch companies with employees that operated within cartels. Only after the 1960s, cartelisation began its decline as a prominent trade strategy. ${ }^{10}$

Many aspects of the cinema trade became subject to NBB rules and regulations. First of all, a standard rental contract was proscribed in 1924, that brought all rental and screening agreements between members under the jurisdiction of NBB regulations. When the economic crisis reached its nadir in the mid-1930s, minimum ticket prices were set in order to prevent cut-throat competition. ${ }^{11}$ Later, rental fees were also controlled. Besides price agreements, many other regulations were introduced to set quality standards and control business practices, covering for instance double billing, $16 \mathrm{~mm}$ and non-commercial rental and exhibition, zoning the market for travelling cinema, regulating television rights, (technical) staff qualifications and labour relations, copyright issues, et cetera. 
The most far-reaching restriction of competition started out with a moratorium on new cinemas. In 1935 the NBB board decided that during the height of the crisis no new cinemas were allowed to open, in order to spare the existing operations that were struggling to survive. This temporary measure was transformed into a permanent procedure: any entrepreneur that wished to open a new cinema needed (and did not always get) approval from a special NBB committee. This restriction remained in place until the NBB was dissolved in 1993. The limitation of new cinema operations obviously would lower the competition between exhibitors. Looking back in 1939, the NBB boasted in its Annual report that only 40 new cinemas were operating since 1935, instead of the 100 that would have opened if no restrictions had been in place. ${ }^{12}$ Until 1947, it was the NBB board that judged each application for a new cinema. After 1947, this authority was bestowed on a special Committee New Businesses ('Commissie Nieuwe Zaken', hereafter CNB), consisting of four NBB members (two exhibitors and two distributors) and a chairman from outside of the industry, appointed by the NBB board. ${ }^{13}$ Furthermore, an Appeals Committee was installed, again with an even number of exhibitors and distributors.

The pre-war policy of restricting the number of new cinemas was continued in the period 1945-1965, when the NBB granted 379 permits for new businesses in the film industry (of which the large majority were cinemas) and it denied 240 applications. ${ }^{14}$ The number of withheld permits is significant, when recognizing that the total number of cinemas increased with 242 in this period (from 323 in 1945 to a peak of 565 in 1961). So in other words: for roughly every new cinema that opened in this period, another cinema operation had been denied access to the market. Of course, this is not to argue that, had there not been a restraint 
on the number of new cinemas, their total amount would have been double, but it does show the scale on which the NBB was manipulating the industry. And these numbers do not take into account the general dissuasive effect of the permit system that would have prevented many would-be cinema exhibitors from even applying.

\section{The Remarkably Slow Reconstruction of the Rotterdam Cinema Park}

In order to get a closer look 'on the ground' at how the growth of the cinema park was restricted by the NBB, we will zoom in on the city of Rotterdam in the years after World War II. Rotterdam offers an interesting case, because, relatively, the number of cinemas was particularly low, showing how even under these extraordinary circumstances, the NBB and the Rotterdam cinema entrepreneurs impeded and delayed the opening of new cinemas.

On 14 May 1940 a large part of the Rotterdam city centre was destroyed by a German air bombardment and the ensuing fire. Of the 19 cinemas, 12 were demolished, among which the largest premiere theatres. Not before 1962 was the pre-war number of 19 cinemas surpassed. Nationally, in 1961 the total number of cinemas reached its all-time peak, whereas Rotterdam counted its highest number of cinemas ten years later. Especially the comparison with the other large Dutch cities is illustrative of Rotterdam's low number of cinemas and seats per capita. According to the NBB's 1952 Annual report, citizens of Amsterdam, The Hague and Utrecht would annually visit the cinema on average 15, 14, and 12 times respectively, 
Rotterdam inhabitants only went 8 times per year. ${ }^{15}$ In 1952, the three largest cities Amsterdam, Rotterdam and, thirdly, The Hague, counted respectively 38, 12 and 26 cinemas, housing $21.514,9.821$, and 18.140 seats. $^{16}$

To be sure, the rebuilding of destroyed cinemas was hindered by factors external to the industry. Directly after the war there was a shortage of building materials. Local and national governments deciding the allocation of building materials and permits, had other priorities reconstructing the wrecked city: repairing the harbour facilities, providing housing, schools, factories and other structures considered more vital to civil and economic life than cinemas. The owners of buildings that had suffered damage in the war were entitled to compensation for their lost properties out of a government fund. But the compensation would not cover the entire losses and it took years before the actual payments came through. ${ }^{17}$ Clearly, this could pose a problem for those exhibitors in need of capital to invest in (re)building. On top of these difficulties, it took time to design and decide on the new lay-out of the city. The urban planners envisaged a modern centre where functional zones for living, working, traffic and entertainment would be clearly delineated. ${ }^{18}$ But the specific implementations of the plans took time to materialise and were adjusted on several occasions. Annual reports of the Rotterdam chapter of the NBB during the late 1940s and early 1950s are filled with complaints how this uncertainty would complicate the decision where to build a new cinema. ${ }^{19}$ Only in the mid-1950s, when new cinemas finally started to emerge, the commercial and theatre districts of the city had become more clearly defined. 
Like elsewhere in the country, Rotterdam exhibitors sighed under heavy cinema taxation, especially after 1948, when the national government dictated local governments to raise entertainment duties. Commercial entertainment was considered by national and local authorities to be a frivolity that discorded with the atmosphere of austerity in the early reconstruction years. So, taxes were raised in order to let the municipality profit from the high demand for amusements: it was clear that cinemas were doing very well these years, especially during the all-time peak in movie attendance in 1946. In 1948 the cinema taxes in Rotterdam were elevated from $25 \%$ to a staggering $35 \%$ of box office takings. Especially the Christian fractions in the city council would voice their antipathy towards film. ${ }^{20}$ But the attitude of local as well as national governments started to shift towards a more positive evaluation of movie going. In order to live up to its ambitions of a reinvigorating modern city, Rotterdam needed its cinemas. Illustrative of this changing mentality, after Rotterdam exhibitors had openly threatened to suspend the rebuilding of cinemas because the taxes would preclude the amortisation of new theatres, the Rotterdam council reduced the taxes in $1954 .^{21}$

In part, the delay in the reconstruction of Rotterdam cinemas can be explained by the external factors outline above. Nonetheless, the specific NBB regulations protected the vested interests of Rotterdam's existing exhibitors, allowing them to slow down rebuilding without the threat of other competitors interfering and forestalling them. They did so by keeping the entry barriers very high, for regular competitors as well as a fringe of entrepreneurs that were operating in the margins of the industry, by applying both general NBB regulations, as well as a specific local decree that was sanctioned by the NBB board. 


\section{Protecting Vested Interests}

The files in the NBB archives show that some of the leading Rotterdam entrepreneurs managed to slow down the rebuilding of cinemas and, during this deliberate delay, keep outsiders out of the market using the NBB's regulations. In 1952, an applicant in an appeal that had been denied a permit to build a cinema in Rotterdam, sorely commented how the low number of cinema seats in the city was 'a very pleasant situation for the Rotterdam exhibitors. Because this is probably the cause Rotterdam has the highest seat occupancy rate of the country. ${ }^{22}$

Like elsewhere in Europe and in the USA, directly after the end of the war, demand for cinema tickets rose to record heights. Those few Rotterdam cinemas remaining in operation were reaping the rich fruits of this movie going craze. For a substantial part, the smaller players benefitted, mostly family-run single-cinema operations, precisely because their cinemas were located outside of the battered city centre. But also bigger exhibitors remained in business. The surviving cinema with the largest seating capacity, Capitol, located west of the centre, was part of the Tuschinski concern, that would turn out as the most prominent company in the post-war market. ${ }^{23}$ Additionally, in the city centre three cinemas were run by enterprises, operating more than a single cinema, in more than one city. 
The proof that, if so desired, rebuilding a cinema could be realised in a rapid tempo is demonstrated by the example of Lutusca. Three major exhibition companies, Scala N.V., City N.V., ('Naamloze Vennootschap’ or 'N.V.' is the Dutch equivalent of a limited liability company) and the Tuschinski concern applied for permits at the municipal authorities to rebuild their destroyed cinemas, hoping to profit as soon as possible from the cinema going boom. Their individual requests were declined because the city administration had other priorities in the allocation of means for urban reconstruction, but the applicants were permitted to erect one single temporary cinema, to be operated jointly. Construction started in March 1946 and the opening took place in time for that year's Christmas season. With a 1000 seats, it was one of the larger theatres of the city. The Lutusca - an acronym for Lumière (the

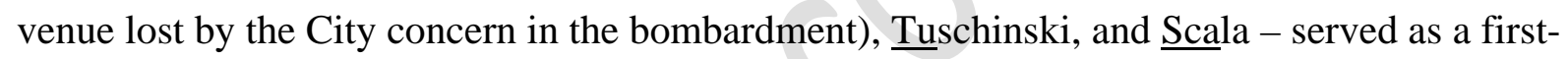
run cinema. Lutusca provided the cooperating competitors, dividing the profits, with a (temporary) outlet for their premieres in Rotterdam from the end of 1946 onwards. Even if forced by circumstances, this close cooperation between rivals appears to be a typical feature of the business mentality in the Dutch cinema industry, tempering free competition, and putting long-term security over short-term profit maximization.

After the quick realisation of Lutusca, the rebuilding of theatres stalled. It took almost a decade before the restoration of the cinema park regained traction. During this time, the number of screens and seats remained very low for a city of the size of Rotterdam, even for Dutch standards. 
The particular circumstances in Rotterdam led the local NBB chapter in 1946 to adopt an agreement called ‘Richtlijnen herbouw Rotterdam’ (Guidelines Reconstruction Rotterdam, hereafter 'Guidelines'), that stated priority rights of those entrepreneurs that had lost a cinema during the 1940 bombardment. ${ }^{24}$ It ruled that no new cinemas could be opened unless by the 1940 victims ('gedupeerden'). The rights for rebuilding could be transferred to other parties. It stipulated that new cinemas could not exceed the seating capacity of the original, destroyed theatre by $20 \%$. The time-bomb in these guidelines was that no deadline was fixed before which the war victims needed to rebuild.

The 'Guidelines' were unanimously agreed to by the members of the local Rotterdam chapter of the NBB, comprising all exhibitors active in the city. A local chapter was always consulted by the CNB when judging an application for a new cinema, in order to give existing exhibitors the opportunity to comment on (and usually protest) the advent of a new competitor. The board of Rotterdam's chapter consisted of representatives of the leading companies that all had suffered war damages and would steer policies in a direction that was beneficial for those entrepreneurs with priority rights. ${ }^{25}$ And those rightful claimants did not exercise their rights for rebuilding until 1955, when they were forced to do so, caused by a chain of events set in motion by a small local competitor. Van 't Hoft ran a small neighbourhood cinema called 'Harmonie' on the south bank of the Maas river. The southern part of the city had been expanding during the first half of the century due to Rotterdam's fast increasing working class population. After the war Rotterdam-South would start growing spectacularly when vast housing projects were planned, practically building a second city on the left river bank. These grand urban expansions promised new markets for cinema 
exhibition. The Tuschinski and City chains were rumoured to plan new cinemas in the South. ${ }^{26}$ Fearing 'competitive excesses and the monopolistic position' of the two largest players in the industry, Van 't Hoft realised that in order to compete with these formidable new contenders, he needed to expand his operation. But since he had not lost a cinema during the 1940 bombardment, he did not have priority rights to open a second cinema. Still, in 1952, he applied for a permit to open a cinema at the CNB, claiming that the war damage victims had not put genuine efforts in realizing new cinemas and after more than five years, the Guidelines ought to be considered void. ${ }^{27}$

As a blatant illustration of how the CNB protected vested interests, in the committee that judged Van 't Hoft's application, two of the four members were his direct competitors, holding priority rights in Rotterdam! E. Alter was employed by the City concern, and C.J. Blad managed the Rotterdam affiliate of the Cineac newsreel theatre chain. Van 't Hoft unsuccessfully objected to the evident bias in the committee. Not very surprisingly, the CNB rejected Van 't Hoft's application. Nevertheless, the case triggered the national NBB board into action. In the summer of 1953 it decided, finally, to set a deadline before which the war victims needed to exercise their priority rights. ${ }^{28}$ This gave Van 't Hoft the opportunity to reapply, and this time, permission was granted to build his Metro cinema, that opened in 1955. In the transcriptions of later (closed) case hearings, the Rotterdam chapter freely admitted to purposefully slowing down the rebuilding of Rotterdam cinemas. ${ }^{29}$ Almost ten years after the temporary Lutusca cinema was built, new theatres started to arise in the city centre. ${ }^{30}$ Using the 'Guidelines' to exclude outsiders from entering the market in the meantime, the main 
Rotterdam players had bought time. Not only did they secure a high seat occupancy in their theatres during a decade of stagnation in the building of new theatres. Also did this strategy allow the entrepreneurs to wait until the new city centre took form without risking the premature intrusion of new competitors. In 1953 the city’s new commercial district was boosted with the famous low-rise Lijnbaan shopping promenade, and in 1954 the opening of several department stores drew in more storekeepers and growing crowds. ${ }^{31}$ Located at the end of the Lijnbaan the urban planners had projected a theatre district, including the new municipal concert hall De Doelen (that was not realised until 1966). Opposite the surviving Luxor theatre, finally, two brand new cinemas opened in 1955. The City-concern exercised its rebuilding rights to erect the Lumière. Next to it rose Thalia, built by the Tuschinski company. In 1957 two more new cinemas opened, when the pre-war Scala was finally rebuilt and a second Cineac cinema opened across the street of the first Cineac (using the priority rights bought in 1949 from the pre-war Asta theatre). In 1961 the Corso cinema was added to the Kruiskade/Lijnbaan theatre district when Chermoek exercised his priority rights. The final use of the rebuilding rights was made by the Tuschinski concern in the opening of the Grand/Studio 62 in 1962, over fifteen years after the Guidelines had taken effect.

The 1960s and 1970s saw an increasing concentration in the exhibition industry accelerated by the disappearance of smaller (family) businesses and fusions and take-overs that led to a devaluation of the NBB as a crucial instrument to control and regulate the market. The minimum price agreements were abolished in $1970 .{ }^{32}$ Two years earlier the association had been restructured, transforming the various regional and local chapters into sections organised by company size. During the 1970s the dwindling number of companies involved in cinema 
exhibition made it hard to even find the members to fill the boards of the sub sections. ${ }^{33} \mathrm{By}$ that time the market was controlled by a genuine oligopoly of large companies, that no longer required the NBB as an organizational framework for their game of 'cautious Stratego' ${ }^{34}$

Besides, the attitudes towards cartel agreements were changing. The influence of the European Community and its less tolerant attitude towards collusion gradually was being felt. Already in 1962, the NBB's president Bosman had reported on his deliberations with officials of the Ministry of Economic Affairs about how the NBB should modify its regulations in order to comply with new policies on competition ('mededingingsbeleid'). ${ }^{35}$ Gradually did European cartel legislation encroach on the NBB, until the organization was finally dissolved in 1993 and replaced by a federation of separate business associations for distributors and exhibitors.

\section{A Fringe of Alternatives: Youth Cinemas, Wild Cinemas, Art Cinemas}

Cartels tend to be more effective when the fringe of entrepreneurs that do not partake in the cartel agreements, is kept as thin as possible. ${ }^{36}$ The preceding section showed the effectiveness of the Rotterdam exhibitors in slowing down the emergence of new cinemas and keeping out outside competitors from opening regular cinemas. But besides the regular exhibition infrastructure, competition from alternative, 'non-commercial' circuits was also thwarted through the use of the NBB regulations, keeping this fringe very small indeed. Even 
though many of these alternative operators had in common that they approached cinema as a social event for the common good, be it entertaining youth that would otherwise take to the streets, or be it uplifting citizens by promoting the 'good' film, asserting cinema as an art form, the boundaries between altruistic and commercial purposes were blurry, which is the reason why the NBB took efforts to keep these alternative circuits in strict containment. In fact, the NBB had been doing so since its inception, by effectively blocking the emergence of a Catholic cinema circuit during the 1920s. ${ }^{37}$ The NBB's course after World War II can be seen as a logical continuation of these earlier policies. When the Reformed Christian youth club ' $t$ Slag' in Rotterdam-South applied for a permit to start a cinema, the CNB and the appeal committee rejected it unequivocally. A cinema, subsidised by a Church organization was considered to be unfair competition to regular exhibitors, 'endangering the healthy development of the existing companies, by disrupting normal [!] competitive relations. ${ }^{38}$ Permitting ‘t Slag to operate a cinema, could work as a precedent or even encouragement for similar youth associations to start up 'subsidised' cinemas. The NBB prevented this from happening in the Netherlands, where 'pillarised' film circuits remained practically nonexistent, meaning that the existence of cinema circuits or even individual cinemas with an explicit religious or political-ideological profile were successfully marginalised by the NBB, distancing the industry from the Catholic, Protestant and Socialist 'pillars'.

Since 1936 the NBB had kept a 'List of no objection' (Lijst van geen bezwaar), a registry containing cultural, social, or educational institutions that - without formal NBB membership - were allowed to screen films, under strict conditions that prevented them from commercially competing with regular exhibitors. In the year after the liberation, demand for 
film had risen sharply, which had given a boost to $16 \mathrm{~mm}$ screenings. ${ }^{39}$ Many non-licensed commercial operators organised travelling shows mostly using $16 \mathrm{~mm}$ projectors and it took the NBB a few years to restore order, by regulating the travelling cinema section of the industry, that continued to thrive in the post-war period. ${ }^{40}$ Also in the so-called 'noncommercial' circuit the increased demand was felt. ${ }^{41}$ Its growth led to the foundation of the Netherlands Film Institute (NFI, Nederlands Filminstituut), an initiative of the NBB in cooperation with representatives of Dutch associational life, such as the Christian association Kerk en Wereld (Church and World). The NFI's first board of directors consisted of some high ranking NBB members combined with prominent advocates of film as a cultural expression. Former Minister of Culture, G. van der Leeuw, acted as first president of this nonprofit organisation, that was made possible by the NBB, that provided start-up capital. ${ }^{42}$ The institute's purpose was to stimulate the artistic and educational value of cinema, by facilitating 'cultural' films for rental. The NFI was de facto an instrument for the NBB to outsource the regulation of the non-commercial circuit. The Netherlands Film Institute was, after adjustment of the NBB regulations in the annual meeting of 1947, the sole supplier for non-commercial films in the Netherlands. ${ }^{43}$ Conditions for film rental were designed to preclude competition to regular exhibitors: ticket prices were subject to strict conditions, advertising was prohibited (which makes it all the harder for the historian to trace these screenings systematically), the organizing association was only permitted to admit members to the private screening, and a film was only allowed if it was not booked that same year by regular exhibitors operating in the same municipality. ${ }^{44}$ 
Cinema audiences consisted increasingly of young people. ${ }^{45}$ Since before the war, youth had been a key concern for the pillarised sociability: ideologically inspired associations with the aim of providing 'responsible' pastime, offering 'healthy' alternatives to the streets, the bars, and other forms of potentially 'harmful' amusements, such as the (mainstream) cinema. Youth clubs and sports or music associations were losing their base to commercial entertainment. ${ }^{46}$ The rise of $16 \mathrm{~mm}$ inflammable film (reducing cumbersome safety issues) expanded the potential for secondary film circuits. These were stimulated by the changing attitude towards cinema as a potentially beneficial tool for providing education and uplift, larded of course with its entertainment value. One of the means to keep youth club members away from the regular cinemas was, of course, to screen films, even though the programmes rented out by the NFI would not nearly be as attractive as the latest releases in the regular cinemas.

The 1951 annual report of the Rotterdam chapter of the NBB complained about associations 'playing' cinema exhibitor ('bioscoopje spelen’), leading to requests to remove some of those associations from the 'List of no objection' ${ }^{47}$ The subsequent annual report explicitly wrote about 'excesses' to which film screenings in 'youth clubs' (jeugdhuizen) had grown. ${ }^{48}$ The fact that the NBB felt the need for stricter regulation in this area suggests that regular exhibitors feared the competition from these alternative circuits and the question is whether they were indeed as 'non-commercial' as they were called. Fact is, that the number of screenings outside of regular Rotterdam cinemas was rising after the war. The city's meticulous administration of cinema taxes allows us to monitor this trend. Even though still quite a marginal phenomenon, the number of tickets sold outside of the regular cinemas rose 
from about $1 \%$ of the total amount before World War II, to over 3\% in 1952. In that year, more than 175.000 tickets were sold for extra-theatrical screenings (in addition to over 3 million regular cinema admissions). On average, ticket prices for these extra-theatrical shows were lower than for regular cinemas, so in terms of market share, this alternative circuit was even smaller, estimated at about $1 \%{ }^{49}$ Even though clearly a small niche, exhibitors noisily resisted this type of competition.

The harshness of the NBB regulations combined with the high demand in the Rotterdam market even drove some into illegality, running so-called 'wild cinemas'. These were cinema operations that were clandestine not only by NBB standards but also sheer unlawful because they operated without a municipal license and were not supervised by authorities inspecting the censorship status of the programme but also safety conditions. A committee installed by the Rotterdam city council reported in 1957 that many of the 'wild cinemas' did not conform to (fire) safety regulations and would sometimes screen films that were unfit for their youthful audiences. ${ }^{50}$ A local press report gives us some idea of what these wild cinemas could look like. In a working class district in the north of the city, a neighbourhood association 'Buurtvereniging Raephorst’ organised a film screening that was interrupted by local police. ${ }^{51}$ In a low ceilinged cellar of 5 by 6 meters about 200 children between the ages of 2 and 12 were standing and sitting to watch a film that lacked the mandatory censorship permit; safety regulations were not met, according to the news report. Tickets cost merely 15 cents. The reporter mentions that this screening was no exception, and many youth associations in Rotterdam screened films. The police had tightened their surveillance and had allegedly encountered several abusive situations, such as an overcrowded room suited for 80 persons 
where 200 children were watching a film; and a case where young children had soiled themselves in response to a film that was not suited for their age. Besides 'bona fide' wild cinemas - as the aforementioned city council committee put it - with the well-meaning intention to divert the idle youth, there were also wild cinemas that were run solely for profit by operators of small halls and pub backrooms. An example of the latter is found in a 1954 newspaper report of the trial of Rotterdam cinema operator 'B.J.W.' and the Amsterdam distributor 'M.D.' that had supplied the films for a clandestine cinema in South-Rotterdam, that screened films for about 400 children three nights a week. ${ }^{52}$ According to a member of the National Censorship Board who was called in as a witness, this was the first case where such a clandestine cinema was shut down by law enforcement, but he suspected the existence of more similar operations. Both accused were convicted to fines and suspended jail sentences.

Besides cinemas specifically targeted at youth audiences, there was a, partly overlapping, dimension of the alternative circuit that was slightly more successful in penetrating the closed Rotterdam market, and that eventually became a niche within the regular circuit: the art film, or 'cultural' film. After the war, the status of film had improved among government and cultural elites in the Netherlands. Cinema was being acknowledged as a potential form of art and as a useful tool of education and cultural uplift. This was reflected in a shifting government attitude towards film as an art form that merited state support through film policies and subsidies, which would hardly have been conceivable before the war. ${ }^{53}$ This was one of the reasons that art film became interesting not only for non-profit organizations but also for commercial entrepreneurs. In Rotterdam, until 1954 a reduced tax rate applied to the 
box office takings for the screening of 'art' or 'cultural' films. ${ }^{54}$ But, more importantly, the composition of audiences was changing: throughout the post-war period movie goers not only were increasingly younger but also had a higher education, undoubtedly increasing the target audiences for art house cinemas and the overlapping category of student cinemas. ${ }^{55}$

Pioneers in this new segment of the industry were Piet Meerburg and Paul Kijzer, who had famously started the student cinema Kriterion in Amsterdam: a 'strange amphibian between idealism and business pragmatism'. ${ }^{56}$ This early and successful example of an art house cinema was run by students. The foundation that owned the cinema operation endeavoured to kill two birds with one stone: allowing a team of students to earn their livelihood in the struggling economy of the late 1940s whilst completing their education, and supplying the intelligentsia with an offering of art films. Kriterion was a success commercially and also in terms of publicity it was warmly welcomed in the Dutch press. ${ }^{57}$

Meerburg and Kijzer made early attempts to enter the Rotterdam market, but it took a lot of staying power and patience to succeed. While they managed to open a second Kriterion in The Hague in 1951, it was only a decade later when Kriterion Rotterdam opened in 1961. Much earlier, the duo had tried to enter Rotterdam’s cinema industry via the Volksuniversiteit in May 1947, an institute promoting the dissemination of the arts and sciences to the general public through courses, lectures and the like. ${ }^{58}$ In the past, the Volksuniversiteit had organised incidental film screenings, as it was on the NBB's 'List of no objection'. The foundation had the ambition to start up a more regular cinema exploitation, doubtlessly hoping to profit from the cinema going craze that had surged in 1946. Piet Meerburg and Paul Kijzer would act as 
managers, programming the 'better' films. The application for a permit was denied by the NBB board on the grounds of the 'Guidelines' since the applicants were no war victims. Perhaps not coincidentally, this rejection occurred at the time when another foundation, the artists' society 'Ons Huis', was applying for a permit in July 1947 for an art house cinema. ${ }^{59}$ In this application to the NBB board the Amsterdam student cinema Kriterion was mentioned as an exemplary business model, providing young artists (instead of students in the Rotterdam case) with a means of support while allowing Rotterdam's cultural elites access to the fruits of international art cinema production. Instead of cooperating with the 'outsiders' Meerburg and Kijzer, 'Ons Huis’ had decided to take aboard the resident small-time exhibitor Emil Weier in the operation. ${ }^{60}$ The NBB board gave permission to start the operation, dubbed 'Het Venster' (The Window), challenging the initial advice of the local NBB chapter. Although not listed as war victim, Weier in fact had lost a venue during the war, since he was incidentally screening films in De Doelen concert hall, that was destroyed in 1940. His loss was taken into account during the NBB board deliberations, together with the fact that the art film operation was not considered a genuine competition because of the small size of the auditorium (184 seats). ${ }^{61}$ Another attempt by Meerburg and Kijzer to be involved in operating the Luxor cinema in 1948 did not succeed either. ${ }^{62}$ Not before 1961 did Piet Meerburg eventually manage to open a new film theatre in Rotterdam, named after the Amsterdam student cinema Kriterion, although not operated by the original Amsterdam student charity foundation, but as a commercial venture by Meerburg and Kijzer. ${ }^{63}$ The Rotterdam chapter of the NBB, as would be expected, advised against Meerburg's plan to open an arthouse cinema. The argument that the city's exhibition sector could not use another competitor had been used consistently by the 
Rotterdam chapter for over a decade. But this time, the CNB permitted Meerburg's theatre, and the decision was upheld after the Rotterdam chapter appealed. During the 1960s Meerburg was mainly responsible for expanding the Rotterdam cinema park; after Kriterion in 1961, he opened Calypso in 1969 and Lijnbaan Theater in 1970. In touch with the new market circumstances of the 1960s Meerburg targeted young and highly educated audiences and built small auditoria that were more cost-efficient than the large (and sometimes out-ofdate) auditoria of many of his competitors. Meerburg created a cinema chain that turned out to be one of the few remaining significant players after the crisis in cinema exhibition deepened during the 1970s. ${ }^{64}$

\section{Conclusion}

An examination of the slow restoration of the Rotterdam cinema exhibition sector after the devastation of 1940, suggests how effective the industry - institutionalised in the NBB fended off outsiders and regulated internal competition. Alternative networks such as youth clubs, religious organizations or the Volksuniversiteit did not succeed in setting up viable film exhibition outlets. The only newcomer that managed to become embedded in the Rotterdam market was Piet Meerburg, but his triumphs started mostly after the global crisis in the industry had set in during the early 1960s, starting a whole new episode in the social and economic history of movie going. During the reconstruction of Rotterdam, the cinema remained a subdued presence, even if in the second half of the 1950s the contours of a modest 
theatre and cinema district had developed in the area around the Kruiskade and Lijnbaan, suggesting that Rotterdam was rising from its ashes as a modern city.

This paper consists of a first, qualitative exploration of the business networks in this specific trade in the city of Rotterdam. A systematic quantitative analysis of business networks would benefit from taking into account at least the other large cities or even nationwide patterns. Another dimension that was not yet taken into account here, is the connections to and combinations with the distribution sector of the industry that was the crucial for many of the larger exhibitors. Instead of widening the scope, another step would be a more in-depth investigation through oral history of the business culture of the Rotterdam cinema industry and its informal rules of conduct and unwritten realities. Some of the entrepreneurs (or their family members) figuring in this narrative, are still alive.

\section{Acknowledgements}

The research for this article was made possible by a Marie Curie Pegasus grant (2015) from the Flemish Research Council (FWO). An earlier version of this paper was presented at the annual conference of the European Association for Urban History (Helsinki, 2016).

\section{References}


Biltereyst, Daniël, Philippe Meers, Kathleen Lotze, and Liesbeth Van de Vijver, 'Negotiating Cinema's Modernity: Strategies of Control and Audience Experiences of Cinema in Belgium, 1930s-1960s', in Cinema, Audiences and Modernity : New Perspectives on European Cinema History, ed. Daniël Biltereyst, Richard Maltby, and Philippe Meers (New York: Routledge, 2012), 186-201.

Bouwens, Bram, and Joost Dankers, Tussen concurrentie en concentratie; belangenorganisaties, kartels, fusies en overnames (Amsterdam: Boom, 2012).

Centraal Bureau voor de statistiek (CBS), Vrije-tijdsbesteding in Nederland, winter 1955/56 (Zeist: De Haan, 1957-1959).

Centraal Bureau voor de statistiek (CBS), Vrije-tijdsbesteding in Nederland 1962-1963. (Hilversum, 1964-1966).

Dankers, Joost, and Bram Bouwens, 'Competition and Varieties of Coordination', in Sluyterman ed., Varieties of Capitalism and Business History: The Dutch Case (New York: Routledge, 2015), 103-129.

Dibbets, Karel. 'Het bioscoopbedrijf tussen twee wereldoorlogen', in: Geschiedenis van de Nederlandse film en bioscoop tot 1940, ed. Karel Dibbets en Frank van der Maden (Weesp: Wereldvenster, 1986), 229-270.

Dibbets, Karel. 'Bioscoopketens in Nederland. Economische concentratie en geografische spreiding van een bedrijfstak, 1928-1977' (master's thesis, University of Amsterdam, 1980).

Dibbets, Karel. 'Neutraal in een verzuild land: het taboe van de Nederlandse filmcultuur.' Tijdschrift voor Mediageschiedenis, 9, no. 2 (2006): 46-64.

Eurostat, Cinema, TV and Radio in the EU, Data 1980 - 2002 (Luxembourg: Office for Official Publications of the European Communities, 2003).

Geurdes, Eva, “"Met uitsluiting van alle anderen...” De tijdrovende wederopbouw van het Rotterdamse bioscoopbedrijf 1945-1962' (master's thesis, Utrecht University, 2015). 
Hertogs, Daan, 'Inleiding', 'Inventaris archief Nederlandse Bioscoopbond', Archief Nederlandse Bioscoopbond [NBB Archives], EYE Film Institute, Amsterdam, ix.

Hes, Jan. In de ban van het beeld. Een filmsociologisch-godsdienstsociologische verkenning (Assen: Van Gorcum, 1972).

Hofstede, Bart, Nederlandse cinema wereldwijd. De internationale positie van de Nederlandse film (Amsterdam: Boekmanstudies, 2000); Bert Hogenkamp, De documentaire film, 1945-1965 (Rotterdam: 010, 2004).

Laar, Paul van de, Stad van formaat. Geschiedenis van Rotterdam in de negentiende en twintigste eeuw (Zwolle: Waanders, 2000) 460-463.

Molenaar, Fjodor, Dana Linssen, Fleur Jurgens ed. Kriterion. Vijftig jaar onderlinge studenten steun (Amsterdam: Spinhuis, 1995), 12.

Oort, Thunnis van. "Christ is Coming to the Elite Cinema": Film Exhibition in the Catholic South of the Netherlands, 1910s and 1920s', in Cinema, Audiences and Modernity : New Perspectives on European Cinema History, ed. Daniël Biltereyst, Richard Maltby, and Philippe Meers (New York: Routledge, 2012), 50-63.

Oort, Thunnis van. "'Coming Up This Weekend": Ambulant Film Exhibition in the Netherlands', In Judith Thissen and Clemens Zimmermann ed. Cinema Beyond the City (Palgrave/British Film Institute, 2017).

Oort, Thunnis van. 'Industrial Organization of Film Exhibitors in the Low Countries: Comparing the Netherlands and Belgium, 1945-1960', Historical Journal of Film, Radio and Television (online 2016), http://dx.doi.org/10.1080/01439685.2016.1157294.

Raymakers, Barry, 'Verstrooiing na noeste arbeid: bioscopen en bioscoopbezoek in Rotterdam, 1945-1970', (master's thesis, Erasmus Universiteit Rotterdam, 1989).

Sedgwick, John, Clara Pafort-Overduin and Jaap Boter. 'Explanations for the Restrained Development of the Dutch Cinema Market in the 1930s', Enterprise \& Society 13, no. 3 (2012): 634-671. 
Sluyterman, Keetie, 'Introduction: Varieties of Capitalism and Business History: The Dutch Case', in Varieties of Capitalism and Business History: The Dutch Case, ed. Idem (New York: Routledge, 2015), 1-21.

Storli, Espen, 'Cartel Theory and Cartel Practice: The Case of the International Aluminum Cartels, 1901-1940', Business History Review 88 (2014): 445-467, there 451-453. doi:10.1017/S0007680514000385.

'Van achtergronden gesproken', Officieel Orgaan van de Nederlandsche Bioscoopbond, 9 November, 1948.

Velden, André van der, Thunnis van Oort and Fransje de Jong, 'De bewogen beginjaren van de Nederlandsche Bioscoop Bond, 1918-1925', Tijdschrift voor Mediageschiedenis 16, no. 2 (2013): 23-42.

\section{Sources}

The 1963 Film Daily Year Book of Motion Pictures (New York: Wid's Films and Film Folk, 1963).

Archief Nederlandse Bioscoopbond [NBB Archives], EYE Film Institute, Amsterdam (NBB). For Annual reports, see also: http://film-bioscoopbranche.nl/.

Film (trade paper; see: http://film-bioscoopbranche.nl/)

Film Year Book (New York: Wid's Films and Film Folk, 1927).

NFI Archive, EYE Film Institute, Amsterdam.

Officieel Orgaan van de Nederlandsche Bioscoopbond

Tijd, De

Vrije Volk, Het 
${ }^{1}$ E.g.: Film Year Book, 945; The 1963 Film Daily Year Book of Motion Pictures, 660-662; Eurostat, Cinema, TV and Radio.

${ }^{2}$ Hes, In de ban van het beeld.

${ }^{3}$ Dibbets, 'Neutraal in een verzuild land'.

${ }^{4}$ Biltereyst et al. 'Negotiating Cinema's Modernity'; van Oort, '“Christ is Coming"'.

${ }^{5}$ Sedgwick, Pafort-Overduin and Boter. 'Explanations'.

${ }^{6}$ van Oort, 'Industrial Organization'.

7 Dibbets, 'Het bioscoopbedrijf'.

${ }^{8}$ van der Velden, van Oort and de Jong, 'De bewogen beginjaren'.

${ }^{9}$ Sluyterman, 'Introduction', 3.

${ }^{10}$ Dankers and Bouwens, 'Competition and Varieties of Coordination', 111-115. See also Bouwens and Dankers, Tussen concurrentie en concentratie. I've addressed this issue of cartelisation in some more detail in: Van Oort, 'Industrial Organization'.

${ }^{11}$ This regulation was abolished in 1971. Film, May 1, 1971, p. 10; See also Film, January 1, 1971, p. 37-38.

${ }^{12}$ Sedgwick, 'Explanations', 14.

${ }^{13}$ Hertogs, 'Inleiding', ix.

${ }^{14}$ These figures, based on the NBB's annual reports, give an indication, but they are complicated. First of all: not all granted permits were realised into actual cinema operations. In addition, there will be duplications in the numbers of applications, granted and denied, because sometimes multiple applications were made for one object. For the turbulent years 1945-1947 we only have an aggregated number of applications for cinemas, as well as distribution and production companies (although cinemas formed the vast majority), for the subsequent years the numbers apply to cinemas only. Furthermore, the NBB introduced the 'B-type' cinema in 1950 , that usually only operated in weekends, as a new administrative category. These permit applications were not included in the statistics, because they were handled by the NBB board, not by the CNB.

${ }^{15}$ Archief Nederlandse Bioscoopbond [NBB Archives], EYE Film Institute, Amsterdam (hereafter: NBB), Annual report 1952, 91.

${ }^{16} \mathrm{NBB}$, File 2840 (93) 'Van 't Hoft, Rotterdam'.

${ }^{17}$ Raymakers, 'Verstrooiing na noeste arbeid'.

${ }^{18}$ van de Laar, Stad van formaat, 460-463.

${ }^{19} \mathrm{NBB}$, Annual reports 1949 and 1952. Raymakers, 'Verstrooiing', 20, 22.

${ }^{20}$ Raymakers, 'Verstrooiing', 16; NBB, Annual report 1954.

${ }^{21}$ NBB, Annual report 1954; Raymakers; NBB, File 2840 (93) 'Van 't Hoft, Rotterdam': In a meeting of the local chapter on 16 October 1952 the Rotterdam exhibitors had decided not to open any new cinemas at least for a year until the city council had lowered the taxes. 
${ }^{22}$ NBB, File 2840 (93) 'Van 't Hoft, Rotterdam'.

${ }^{23}$ Geurdes, “"Met uitsluiting"', 28.

${ }^{24}$ The guidelines were drafted in 1946, and altered in 1948. At present, only the 1948 version of the document has been recovered. NBB, File 2840 (93) 'Van 't Hoft, Rotterdam'.

25 Geurdes, '"Met uitsluiting"', 30

${ }^{26}$ NBB, File 2843 (137) Tuschinski, Amsterdam. Tuschinski did apply for a permit to build a cinema on Zuidplein in 1954; it was granted but the cinema was never realised.

${ }^{27}$ NBB, File 2840 (93) 'Van 't Hoft, Rotterdam'.

${ }^{28}$ NBB, Annual report 1954, 40. Entrepreneurs intending to exercise their priority right needed to make a plot reservation at the municipal administration before 1 February 1954 Later, dispensation was granted, extending the deadline. Tuschinski would still exercise it as late as 1961.

${ }^{29}$ NBB, File 2855 (272) Romef.

${ }^{30}$ The first being Vermeer's single-cinema operation that reopened the Centraal cinema in a new building in 1953.

${ }^{31}$ van de Laar, Stad van formaat, 469.

32 NBB, Annual report 1970.

${ }^{33}$ NBB, Annual report 1978.

34 Dibbets, 'Bioscoopketens'; Film, 1 August, 1987.

${ }^{35}$ Film, 1 November, 1962. In the case of the ' $t$ Slag youth club cinema, applicants referred to an earlier interference of the Ministry of Economic Affairs in 1957. NBB, File 2856 (280) Jeugdhuis 't Slag, Rotterdam.

${ }^{36}$ Storli, 'Cartel Theory', 451-453.

37 van Oort, "'Christ is Coming"'.

${ }^{38}$ Concept version verdict Appeal Committee (Dated 12 December 1960, but redacted later in December according to the accompanying letter), NBB, File 2856 (280) Jeugdhuis 't Slag, Rotterdam.

39 'Van achtergronden gesproken'.

${ }^{40}$ van Oort, "'Coming Up This Weekend"'.

${ }^{41}$ NBB, Annual report 1948. In 3 years after the liberation in May 1945, 2637 non-commercial programmes were supplied, which is considered a very high number in the report.

42 The notary foundation statute dated 10 April,1948 mentions Joh. Miedema, M. Vermin, J. Weening and J. Nijland as representatives from the NBB and A. van Domburg, J. Knipping, G. van der Leeuw, J.Rupp and D. van Staveren as additional board members. The NBB provided the new foundation with fl. 1.000,-. NFI Archive, File 1 , 'Statuten'. 
${ }^{43}$ NBB, File 306 Bedrijfsreglement op de Lijst van geen bezwaar; Officieel Orgaan van de Nederlandsche Bioscoopbond 18 August, 1948. Though, typically, exceptions were made for some companies that had specialised in this niche market.

${ }^{44}$ NBB, File 2856 (280) Jeugdhuis 't Slag, Rotterdam. The operators of the cinema in 't Slag youth club complained that they were not allowed to sell any tickets, nor advertise the show. But the municipal tax records show that non-commercial film screenings usually did have entrance fees, although lower than regular cinemas. The NFI catalogue contains the following general statement on rental conditions: 'The NFI makes films available for private, non-commercial screenings, with cultural or social purposes. In no case can a financial goal be pursued. The screenings should be organised in such a manner, that they do not compete with local cinemas or travelling cinemas.' NFI Archive, File 223.

${ }^{45}$ Centraal Bureau voor de statistiek (hereafter CBS), Vrije-tijdsbesteding in Nederland, winter 1955/56. CBS, Vrije-tijdsbesteding in Nederland 1962-1963.

${ }^{46}$ Ibid. Associational life among youths was declining and commercial leisure rising.

${ }^{47}$ NBB, Annual report 1951.

${ }^{48}$ NBB, Annual report 1952.

${ }^{49}$ The annual reports of the city of Rotterdam state how many tickets were sold in various price categories. This allows for an estimate of the box office takings per category. Extra-theatrical screenings often charged between 10 and 25 cents, regular cinemas usually charged more than that. Screening 'cultural' films required a lower tax rate until this special tariff was abolished in 1954: $20 \%$ instead of $35 \%$. These statistics do not take into account the illegal 'wild' cinemas that also popped up, because obviously they would not pay taxes.

${ }^{50}$ Film 1 August, 1957; Raymakers, 'Verstrooiing', 19.

${ }^{51}$ Het Vrije Volk, 23 March, 1954.

${ }^{52}$ De Tijd 12 March, 1954; 25 March, 1954; 8 June, 1954.

${ }^{53}$ Hofstede, Nederlandse cinema wereldwijd; Hogenkamp, De documentaire film.

${ }^{54}$ This special tariff was abolished in 1954. NBB, Annual report 1954. In many other municipalities a similar special low tariff for 'cultural' (or Dutch) films existed.

${ }^{55}$ CBS, Vrije-tijdsbesteding 1955/56; CBS, Vrije-tijdsbesteding 1962-1963.

${ }^{56}$ Molenaar, Linssen, Jurgens ed. Kriterion, 12 . The original phrase 'vreemde amfibie van idealisme en zakelijkheid' originates from journalist Jan Vrijman at the occasion of the 10th anniversary of Kriterion.

${ }^{57}$ Ibid., 20-21

${ }^{58}$ NBB, File 2819 (472) City, Rotterdam.

${ }^{59}$ NBB, File 2821 (517) Ons Huis, Rotterdam.

${ }^{60}$ Weier had followed in his father's footsteps after 1940, operating a travelling cinema in the region, and a temporary cinema in Rotterdam during the war, and who opened the Courzand cinema in 1942, located in a remote industrial district in the harbour. 
${ }^{61}$ Officieel Orgaan van de Nederlandsche Bioscoopbond 22 April, 1948. Minutes Board of Executives NBB 27 January, 1948.

${ }^{62}$ Minutes Board of Executives NBB 13 April, 1948; NBB, File 2819 (472) City, Rotterdam.

${ }^{63}$ NBB, File 2855 (272) Romef.

${ }^{64}$ Dibbets, 'Bioscoopketens'. 